\title{
O TRABALHO E O MOVIMENTO NAS TRAMAS URBANAS: CONDIÇÃO DE MOBILIDADE E RECURSO SOCIAL DE CATADORES DE MATERIAIS RECICLÁVEIS
}

\author{
Work-related experiences and action in urban storylines: recyclable material \\ collectors condition of mobility and social resource
}

Ari Rocha da Silva ${ }^{1}$

\begin{abstract}
Resumo
0 artigo articula uma reflexão a respeito dos ajustamentos e mediações que acontecem nos espaços das ruas e das casas de trabalhadores que catam materiais recicláveis na cidade de Passo Fundo / RS. Dessa forma, concentra uma análise que diz respeito ao trabalho desenvolvido por um importante e atualíssimo segmento social que cada vez mais representa um público de trabalhadores que executam atividades alternativas e informais pelas ruas de cidades brasileiras. Buscamos com isso, perceber os movimentos e as mobilidades de atores que usam suas capacidades relacionais para de alguma forma determinar e garantir seus modos de vida e contornos íntimos, subjetivos e culturais. A pesquisa empírica foi desenvolvida nos anos de 2015-16, onde foram abordados nas ruas e nas associações de trabalho 120 catadores para que pudéssemos conhecer o perfil dos trabalhadores dessa cidade, sendo entrevistados e observados 22 desses trabalhadores (entrevistas narrativas) em seus locais de trabalho e moradia visando compreender suas trajetórias e experiências pessoais. Assim, a pesquisa nos orientou a perceber como tais atores são heterogêneos e dinâmicos em suas trajetórias de vida e trabalho, seja integrando-se a diferentes grupos sociais, agindo estratégica e taticamente e exercendo capacidades subjetivas diante de possibilidades e obstáculos sociais estabelecidos ao longo de suas experiências de vida.
\end{abstract}

Palavras-chave: Trabalho; Ação Social; Catadores de materiais recicláveis; Mobilidade; Informalidade.

\begin{abstract}
The article articulates a reflection about the adjustments and mediations that take place on the streets and homes of workers who collect recyclable materials in the city of Passo Fundo / RS. Therefore, it concentrates an analysis concerning the work that has been developed by an important and very current social segment that, increasingly, represents a community of workers that performs alternative and informal activities through Brazilian streets. It is aimed to understand the movements and nobilities of participants that use their relational capacities to somehow determine and guarantee their ways of life and intimate contouring, which are also subjective and cultural. The empirical research was developed in the years of 2015-16, when
\end{abstract}

\footnotetext{
1 Professor do Instituto Federal do Rio Grande do Sul (IFRS) - Campus Feliz e doutor em Ciências Sociais pela Universidade do Vale do Rio dos Sinos, UNISINOS, São Leopoldo, RS, Brasil. E-mail: rsari@ig.com.br.
} 
120 collectors were approached on the streets and in the labor association to be possible to understand the workers' profile, from these 120 workers, 22 of them had been interviewed (narrative interviews) and observed in their work places and homes, therefore it could be possible to understand their personal background and experiences. Thus, the research has guided us to understand how these participants are heterogeneous and dynamic in their life and work backgrounds, integrating themselves with different social groups, acting strategically and tactically and exercising subjective abilities in the face of social possibilities and obstacles established through their lifelong experiences.

Key words: Work; Social Action; Recyclable Material Collectors; Mobility; Informality.

Este artigo tem como dimensão o vivido por um segmento de trabalhadores urbanos, especificamente, catadores de materiais recicláveis. As problemáticas aqui discutidas emolduram as franjas e a centralidade das ações desenvolvidas por esses atores sociais a partir de suas experiências de vida permeadas de sentidos e identificações com o trabalho que executam. Definimos os catadores de materiais recicláveis como atores sociais na medida em que os percebemos cotidianamente em diferentes cidades do planeta, onde participam e se relacionam de diferentes formas na sociedade, desenvolvendo um importante trabalho na cadeia de reciclagem de materiais que são descartados pela população em geral. Com isso, nosso propósito aqui tem como desígnio destacar algumas lógicas e práticas de catadores em uma determinada cidade do Brasil, Passo Fundo, norte do Rio Grande do Sul.2 Cidade essa, por suas dimensões econômicas acentuadas na área de serviços, educação e como suporte de uma região voltada ao agronegócio, configura-se como polo da região norte do Estado, atraindo diversos segmentos sociais e migrantes, muitos dos quais, trabalhadores rurais que foram dispensados do trabalho do campo a medida que o processo de modernização das lavouras tornou parte da mão de obra obsoleta nas últimas décadas.

Com o auxílio inicial da perspectiva teórica de Castells (1999), partimos do pressuposto que o espaço urbano e regional se conecta a uma rede de encaminhamentos, interesses e ações que também dizem respeito à dimensão

2 O município de Passo Fundo é composto por uma população de 184.825 pessoas, sendo que 180.120 $(97,4 \%)$ vivem na área urbana e $4.705(2,54)$ na área rural (Censo demográfico - IBGE, 2010). Estimativa em 2015 era de uma população total de 196.739 pessoas (IBGE). 
globalizante de relacionamentos e negócios. Por outra parte, esta mesma dimensão urbana e regional faz a mediação em relação a outros espaços mais circunscritos da realidade social local, espaços esses amparados por ações mais imediatas e próximas dos indivíduos, podendo ser aqui representados pelo ambiente comunitário ou familiar, ou seja, por uma base relacional que enlaça as formas locais e intimistas em relação aos sujeitos que buscamos destacar. Por nossa ênfase, o espaço circunscrito às ações concretas dos indivíduos será aqui tratado como horizonte fundamental de suas práticas e relacionamentos, onde se busca perceber de forma concreta os movimentos do dia a dia, aquilo que, de certa forma, consubstancia as experiências e posições dos sujeitos diante das possibilidades e dos obstáculos que encontram para criar e desenvolver ações cotidianas de trabalho.

Frisa-se, enfim, o espaço local e as diferentes formas que os sujeitos conjugam para viver e agir contornando as providências do cotidiano e que perfazem às lógicas sociais da integração, da estratégia e da subjetivação. Lógicas essas salientadas por François Dubet (1994) ao concatenar sua Sociologia das Experiências e ao retratar em teoria as dinâmicas que envolvem todos os atores sociais e o ciclo de relações estabelecidos por eles mesmos. Em certo sentido, Dubet irá provocar uma reflexão crítica das grandes interpretações sistêmicas da reflexão sociológica, o qual reputa não ser possível analisar as transformações sociais a partir de grandes escalas e determinações sociais. Por outro lado, também faz a crítica às interpretações metodológicas que se amparam nas iniciativas meramente individuais e das escolhas racionais. Dessa forma, enlaça em sua interpretação a proposta de análise das lógicas sociais conjugadas e independentes dos atores que se movimentam no espaço das relações sociais, pois os indivíduos afixam a lógica de busca constante voltada à integração aos espaços de convivência, inserindo-se em práticas e regras comuns ao grupo em que participam, embora não deixem de exercer faculdades lógicas estratégicas e subjetivas amparadas por reflexões racionalizadas e por apreensões culturais-valorativas, respectivamente. 
Salientamos também nesse trabalho o aspecto tático desenvolvidos pelos atores, muito ao gosto de Michel de Certeau (1998), ao analisar os sujeitos comuns em suas práticas ordinárias que caracterizam jeitos de ser e fazer as coisas em suas relações subalternas e dependentes. Isso denota, em nosso ponto de vista, o caráter repleto de tensões, práticas, formas de expressão, entendimentos da realidade e conhecimentos adquiridos ao longo das experiências vividas pelos sujeitos em questão; o que, de certa forma os tornam igualmente ativos e maleáveis diante de contextos e possibilidades comuns e variadas.

Para que esta reflexão fosse fundamentada, percorremos todos os setores da cidade de Passo Fundo, nos anos de 2015 e 2016, buscando estabelecer contatos de forma aleatória com todos os catadores que avistássemos nas ruas da cidade, bem como estabelecemos contato com todas as associações de trabalho que identificamos na localidade. Essa primeira fase da pesquisa foi realizada mediante um questionário socioeconômico com o objetivo meramente exploratório para auxiliar-nos no conhecimento de algumas práticas e a respeito do perfil destes trabalhadores (foram, nesse momento, questionados 120 catadores no exercício de suas atividades). Num segundo momento, escolhemos 22 desses catadores para entrevistarmos (entrevistas narrativas) com o intuito de aprofundar nossa investigação e compreender suas trajetórias de vida e trabalho. A escolha desses 22 catadores teve como critério a diversidade de suas localizações espaciais, idades, gêneros, formas de trabalho e condições socioeconômicas.

Efetivamente, estas duas formas de imersão no campo de estudo nos serviram para irmos modulando nossas observações e em momentos posteriores e continuos irmos participando de alguns episódios do dia a dia de alguns catadores, visitando suas casas e seus espaços de reuniões e sociabilidades, como cultos religiosos e encontros de família. De forma geral, os trabalhadores foram muitos solícitos em nos receber e conversar em seus locais cotidianos, onde tivemos a oportunidade de observar e conhecer suas 
trajetórias, condições de trabalho e experiências de vida que os auxiliaram a investir no campo de trabalho da reciclagem de materiais.

Em última análise, o objetivo do trabalho, seguindo nossa proposta, foi de compreender dessa forma as lógicas sociais e práticas desenvolvidas pelos catadores, em meio a um ambiente de intensas transformações sociais que caracterizam as grandes e médias cidades atuais. Assim, aliado e concomitantemente aos levantamentos de dados anteriores, realizamos várias observações diretas junto ao público investigado, seja nas ruas da cidade, associações de trabalho ou em seus espaços íntimos de suas casas, o que de certa forma nos possibilitou aprofundar nossa análise social e entender com maior rigor e profundidade o movimento e a dinâmica desses sujeitos pela cidade. Assim, consideramos que o percurso metodológico de nossa investigação se caracteriza por uma metodologia mista da apreensão da realidade, envolvendo questionários, entrevistas e observações diretas (com forte teor etnográfico) junto a um contingente de catadores da cidade de Passo Fundo.

$\mathrm{Na}$ primeira seção do artigo, Processos de ajustamentos e mediações, abarcamos os processos de inserção dos sujeitos em seus locais de vida cotidiana e trabalho. Ou seja, focamos nossa análise em sujeitos que vão condicionando e sendo condicionados no espaço de relações sociais e que irão produzir adaptações e assimilações no ambiente em que se inserem. Para isso, a casa, as rotinas no espaço comunitário e os pactos realizados serão aqui enfatizados, possibilitando-nos identificar os horizontes associativos primários e os lastros relacionais que se imbricam para que haja certa reciprocidade entre indivíduos em diferentes e semelhantes momentos de suas ligações. Assim também será discutido o caráter da importância dos aspectos conectivos entre trabalho e vida cotidiana, elencando o espaço da rua e dos contatos construídos nos percursos pela cidade.

Para além das questões da seção anterior, a segunda seção deste artigo, Associação e individualização estratégica, busca fazer referências tanto às 
condições contextuais que se dirigem a alçada da constituição de grupos de trabalhos formais e informais, quanto a maneira em que estes grupos são de alguma forma constituídos. Prioriza-se, porém, o impacto das relações de poder nos grupos populares buscando compreender as instancias recursais e poderes intrínsecos às dinâmicas de relacionamentos hierárquicos que possam estar em jogo em determinados contextos e ações.

$\mathrm{Na}$ última seção, Vai indo, vai indo - movimento como recurso constante $e$ totalizante, estabelecemos de forma mais enfática uma relação entre trabalho e os aportes estratégicos e táticos dos catadores, buscando demonstrar a necessidade de mobilidade espacial por parte desses sujeitos na medida em que visam interceder na sociedade em função de seu trabalho e das formas e visões que detêm. Assim, a possibilidade do movimento espacial e o permanente foco em busca de oportunidades e recursos a serem explorados pelos próprios trabalhadores serão frisados nesta sessão a partir das lógicas e responsabilidades configuradas cultural e subjetivamente, nas quais se processam pactos associativos e individualizações racionalizadas por parte daqueles que agem no espaço do lugar.

Acreditamos que, dessa forma, poderemos tratar de várias práticas sociais e relações desenvolvidas pelos catadores a medida em que se caracterizam por serem sujeitos atuais e importantes de serem compreendidos em nossas sociedades, distante de ideias pré-concebidas que os caracterizam como sujeitos meramente vulneráveis e desconexos da sociedade abrangente. Os catadores, segundo nossa percepção, fazem parte de um segmento social que se notabiliza por suas movimentações nas cidades realizando um trabalho de suma importância, assim como fazem parte de um estrato de trabalhadores que em certa altura da vida se encontraram desvinculado do trabalho formalizado, seja no ambiente rural ou urbano, muito embora sejam propositivos em suas práticas e atuantes nas suas formas de ser e estar catador. Dessa forma, compreender suas trajetórias em meio a suas necessidades, escolhas e configurações culturais nos ajuda a pensar o trabalho em nossas sociedades e os motivos das ações consoantes a determinadas 
vivências, ajustes e adaptações criadas por eles e outros atores sociais que têm no espaço da rua o ambiente para definir suas práticas sociais.

\section{Processos de ajustamentos e mediações}

Ao buscar compreender como se estabelecem trajetórias sociais de indivíduos determinados, pudemos constatar o quanto ainda são sistemáticos os movimentos migratórios em um determinado território, seja no sentido mais clássico da ação migratória, do abandono definitivo do meio rural em direção à cidade ou de cidades para cidades, ou daquelas movimentações temporárias relacionadas a vínculos transitórios ou estágios delimitados pela empregabilidade em um determinado lugar.

No contexto da pesquisa que elaboramos na cidade de Passo Fundo / RS, as possibilidades de mudanças e movimentos estão relativamente abertas para serem pensadas e aproveitadas por sujeitos que executam o trabalho de catação de materiais recicláveis nesta localidade, independentemente de sua origem e condição em determinadas escalas socioeconômicas. Alguns aspectos chamam a atenção no que se refere às motivações migratórias relacionadas ao público que pesquisamos, pois são muito fortes os desenlaces das famílias que se encontram no meio rural e que se dirigem à cidade pela falta de emprego ou insustentabilidade econômica da propriedade rural a que estavam vinculados. São visiveis também os fenômenos da insustentabilidade de padrões de trabalho tradicional na cidade à medida que novos padrões tecnológicos foram universalizados e as lógicas do mercado redefinidas com ênfase em investimentos tecnológicos e novos padrões e qualificações de produção.

A título de exemplo, alguns dos trabalhadores que tivemos a oportunidade de contatar denunciaram que sofreram pressões oriundas das ameaças de violência por parte de proprietários rurais para que deixassem suas terras. "Eram verdadeiros bandidos", relata um de nossos entrevistados que foi expulso de suas terras junto com sua família quando ainda era adolescente, algumas décadas atrás. Tais violências nada mais são do que os efeitos de uma 
outra lógica do uso do solo rural e da supervalorização de cunho extensivo e capitalista da produção agrícola moderna. A condição de vida no campo, nesse sentido, torna-se extremamente incerta pela instalação de um novo arcabouço tecnológico e empreendedor no campo, aliado a isso a aviltante e desigual disputa pelo poder no espaço rural e pela falta de sustentabilidade comercial da produção e do consumo dos pequenos agricultores locais. ${ }^{3}$

A migração, no entanto, também pode ser explicada por outros motivos, embora relacionados àqueles. Pois nos chamou muito a atenção a procura por assistência à saúde por parte de nossos entrevistados, oriundos de outros estados, inclusive. Alguns demarcaram suas movimentações para a cidade pela possibilidade de estarem melhor assistidos por serviços de saúde nessa cidade de referência. É muito marcante este aspecto nas falas dos pesquisados em função do adoecimento de algum parente que, em um determinado momento, necessitou de atendimento médico de forma mais intensiva e recorrente. A moradia em pequenas cidades ou meio rural e, consequentemente, a vinda a Passo Fundo de forma sistemática para tratamento de saúde, torna-se um fator que leva muitos indivíduos a se fixarem definitivamente nessa cidade. ${ }^{4}$

A migração rural-urbano, porém, como mencionamos, não é algo de mão única, campo-cidade. Isso também está disposto nos exemplos derivados de nossos informantes. Algumas tentativas de retorno ao meio rural e sua subsequente desistência e definitivo retorno à cidade de Passo Fundo foram também apontados. Principalmente para aqueles que ainda possuem referências culturais e disposições sociais voltadas para o ambiente rural, possuindo, inclusive, parentes e conhecidos no interior de alguma cidade próxima a esta localidade. Há também aqueles que não possuem nenhuma

\footnotetext{
3 Cabe lembrar que o Norte do estado do RS, da qual a região de Passo Fundo faz parte, é o berço de muitos conflitos rurais, envolvendo não apenas proprietários e trabalhadores rurais sem-terra, mas uma gama de outros atores sociais como indigenas, comunidades quilombolas e atingidos por barragens, o que torna este meio bastante complexo e cheio de nuances politicas, econômicas e culturais em seu desenvolvimento histórico (RÜCKERT, 1997; TEDESCO, CARINI, 2010).

4 Passo Fundo tornou-se já alguns anos um dos principais polos de atendimento médico do RS, inclusive com cursos universitários de medicina instaurados no município, sendo uma cidade atrativa de imigrantes que buscam atendimento médico nas diversas especialidades que o complexo de saúde local disponibiliza.
} 
referência com o meio rural, mas podem desenvolver alguma atividade nas lavouras, como carregador de cereais em caminhões, transportador agrícola ou, até mesmo, trabalhando na colheita e no beneficiamento de produtos sazonais em meio a outros trabalhadores, dispondo sua mão de obra barata e desqualificada a contratantes e proprietários rurais. Geralmente esses trabalhadores, homens e mulheres, são recrutados na cidade na forma de "empreitada de trabalho", o que se torna uma opção de atividade laboral àqueles que transitam pela cidade à procura de emprego.

Tivemos oportunidade de conhecer várias histórias e experiências de vida ao longo de nossa pesquisa. Como exemplo, identificamos uma dupla de catadores que moram na rua, sem habitação própria, onde o mais velho (30 anos), um típico imigrante de origem rural, contou-nos que veio para a cidade sem nenhum suporte material ou contato prévio para instalar-se na localidade. Esse sujeito, o mais propositivo para conversar e responder nossos questionamentos, está em Passo Fundo há 4 anos, possui um semblante realmente muito marcado pelo trabalho no meio rural, com chapéu de palha e linguagem muito própria do homem rural, diferente de seu companheiro (24 anos) que possui traços muito mais próprios de um jovem citadino da periferia, com boné, óculos escuros e roupas coloridas, ao estilo funk de alguns jovens moradores de bairros populares urbanos atuais (Fotografia 1). Disseram que executam a catação de forma parcial, pois declararam que conseguem exercer algumas atividades fora da reciclagem, como cortar grama em ambientes domésticos e executar pequenos serviços quando demandados pelas pessoas que os conhecem ou os veem passar com o carrinho de catação. Declararam que quando cansam param o carrinho para descansar na companhia de seus cachorros que são seus "cães de guarda", pois os protegem durante a noite de qualquer eventual ataque que possam sofrer de pessoas desconhecidas. De alguma forma, podem ser definidos como nômades urbanos a medida que não 
possuem pontos fixos de descanso, muito menos um local para passar a noite na cidade. 5

Revela, ainda, o mais velho, que veio para Passo Fundo quando "perdeu a mãe" (por seu falecimento). Quis tentar a vida em outro lugar, deixando tudo para trás, inclusive a companhia da filha. Já trabalhou como pedreiro, borracheiro e soldador em outra cidade em que morava. Falou que o bom da sua forma de trabalho atual é o fato de não precisar ser mandado por ninguém: "não tenho chefe", declara taxativamente. Além disso, acham coisas boas no lixo para usar e vender. Ganhavam, cada um, 200 reais em média por mês na catação (abril - 2015).

Fotografia I - Catadores de materiais recicláveis moradores de rua

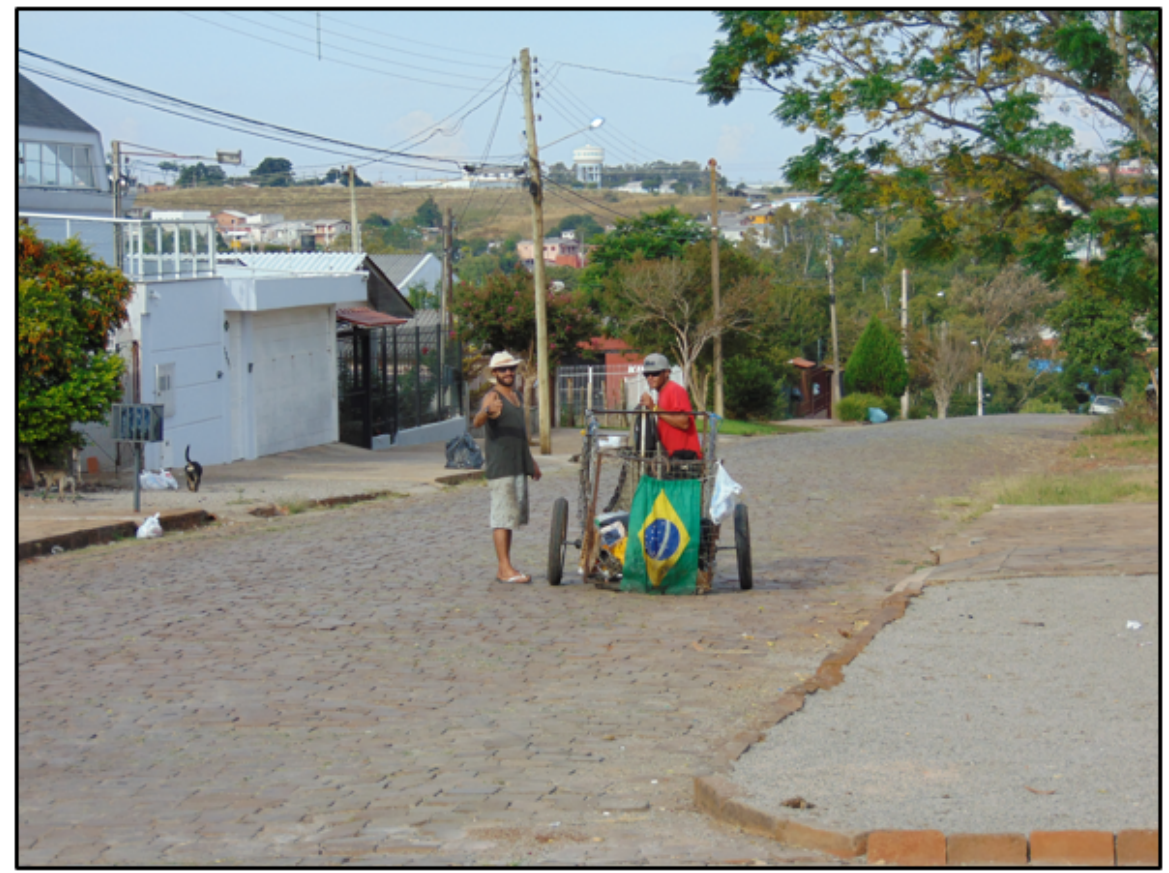

Fonte: acervo do autor - 13 de abril de 2015.

5 Magni (2006), "Nomadismo Urbano: uma etnografia sobre moradores de rua em Porto Alegre", faz um relato de sua experiência de pesquisa junto a moradores de rua na cidade de Porto Alegre. A autora teve a oportunidade de conviver por vários meses com grupos de moradores de rua, em seus ambientes de moradia (acampamentos) e compreender seus modos de vida e sobrevivências. Cabe o destaque das diferentes facetas, dos traumas e processos cotidianos atrelados à vida na cidade de Porto Alegre e como esses nômades se identificam e promovem suas formas de relações. Em nosso trabalho deparamo-nos com alguns nômades urbanos realizando o trabalho da reciclagem, embora não tenha sido especificamente o objeto de nossa pesquisa, o que demonstra a heterogeneidade dos catadores na cidade de Passo Fundo, pois o público pesquisado se amplifica, desde o morador de rua mais precarizado, alguns dependentes do uso de drogas, ao catador mais formalizado, direcionado ao empreendimento da catação e do aprimoramento de suas técnicas de trabalho. 
A bandeira do Brasil fixada e estampada no carrinho tornou-se emblemática à nossa percepção, questão referencial para os sujeitos que, de alguma forma, buscam integrar-se a uma sociedade e empenhar suas ações dentro de uma lógica de trabalho que os condicione a buscar certa liberdade, manifestando suas diferenças entre si e entre o público com que estabelecem contato de forma sistemática e eventual pelas ruas da cidade.

O pêndulo que balança para o lado do acolhimento dessas pessoas na sociedade, explorando sua mão de obra barata e informal, é o mesmo que vai ao extremo oposto, que os repudia, que os isola, condição que os afeta e que os faz buscar defesa em relação à violência física e moral que sofrem. Tais fenômenos são a base para que os sujeitos racionalizem suas práticas visando sua preservação, sejam táticas, utilizando a afetividade dos animais que os seguem e os protegem durante a noite, sejam estratégicas, rompendo vínculos de mando e submissão. Ao mesmo tempo, de forma independente, também estampam a bandeira brasileira no carrinho com o qual trabalham e, assim, poder dizer, de forma consciente ou inconsciente, que também são brasileiros, que fazem parte do conjunto da nação, que são cidadãos com direitos, em certo sentido iguais a todos os outros.

Ao estarem em sintonia e serem propositivos em suas ações e reações, permitimo-nos a pensá-los como formas de resistências e de um jeito próprio de fazer as coisas que são demandadas a eles. A dualidade da vida desse exemplo mostra-se muito forte, uma vez que esses atores estão em trânsito permanente, por isso se utilizam de ações pontuais que sinalizam suas posições. Perpassam a cidade, mostram-se visiveis e ativos, organizam ações de proteção e afluência nos espaços públicos. Esses são contornos imediatos e intensos ao elaborarem mecanismos visíveis no cuidado de si e de seu próximo, às vezes aceitando o amparo de alguém que os usa como mão de obra barata; em outros casos, eles mesmos repudiam os hábitos que querem imputar-lhes, não respeitando as lógicas formais do trabalho. Dessa forma, rechaçam o ordenamento e a 
regulação, colocando-se em marcha e distanciando-se em relação a parâmetros hierárquicos de poder e aos mecanismos normativos do trabalho formal.

A exemplo desses catadores, migrantes na/da cidade de Passo Fundo, condicionados por questões estruturais e circunstanciais, sem nenhuma dessas dimensões eliminar a outra, revelam posteriormente as condições de mediações e ajustamentos que lhes permitem de algum modo se fixarem na cidade. Os apoios e as configurações de ajuda mútua serão, em suas trajetórias, fundamentais para que incorporem algumas dinâmicas dos lugares em que adquirem a oportunidade de morarem ou apenas transitarem. Embora, conforme pudemos observar, nenhum lugar é definitivo, principalmente nos primeiros anos da chegada dos que vem "de fora" que investem na mobilidade espacial. Determinadas acomodações de fixação levarão algum tempo para serem definitivas ou, até mesmo, nunca se revelarem permanentes, embora fundamentais para ampliação dos horizontes e percepções das oportunidades oferecidas, entre as quais a catação de materiais recicláveis torna-se um anteparo importante, seja de ganho econômico ou como simples forma de circulação pelas ruas da cidade para a apreensão de outras oportunidades de trabalho.

O ingresso no trabalho como catador nunca é uma experiência isolada, condição que diga respeito apenas ao indivíduo que acessa tal atividade laboral. As condicionantes de trabalho, geralmente, possuem lastros matizados pelas relações familiares e de vizinhança. Tanto para quem chega no espaço comunitário ou para quem já se encontra nas redes de relações dessa natureza, os aportes familiares e de vizinhança são aspectos imprescindiveis para a inserção dos sujeitos que buscam a participação no grupo social a partir das atividades econômicas que passam a ocupar, sejam elas as mais variadas possiveis, sejam no próprio espaço doméstico, no ambiente arruado ou das cooperativas de trabalho.

Para o acesso a uma atividade econômica, a socialização dos conhecimentos e informações é indispensável. Muitas vezes isso acontece no contínuo das relações, sem necessariamente formalizar-se um começo desse 
processo de inserção do aprendizado do trabalho. Em geral, pais catadores recebem ajuda de seus filhos e netos em determinadas atividades do dia a dia. Raramente os catadores impedem seus descendentes de tal atividade. Lourdes (catadora, 50 anos) foi uma exceção em nossa amostra: "os jovens não devem mexer no lixo, devem fazer outra coisa melhor". Por outro lado, não foram poucos os casos em que os filhos inseriram os pais na atividade de catação, mostrando as vantagens e encaminhando os mais velhos para o exercício da função. De qualquer forma, trata-se de uma atividade sempre avivada no seio das famílias, fundo de reserva para quem busca ter uma renda em um determinado momento; para outros é a ocupação principal, ambas legitimadas pelos grupos que dela participam.

Aprender com os vizinhos o trabalho de catação, de certa forma, torna-se também um parâmetro de socialização das atividades e de divisão de experiências e aprendizados. Cria-se de alguma maneira uma cultura da catação que estrutura formas práticas de atuação, além de ser um salvo conduto para que se atue nesta atividade, pois "se o vizinho cata, porque eu não posso catar, não é vergonha pra ninguém!' (Soraia, catadora, 60 anos)

A vergonha de mexer no lixo relativiza-se e cria uma carapaça social aludida pela naturalidade de lidar com materiais recicláveis. Diante da possivel indignidade de mexer no material que outras pessoas desprezam, que jogam fora, a catação torna-se uma atividade comum e espontânea. À medida que todos catam rompe-se em parte a perspectiva de um trabalho meramente inferiorizado, indigno e restritivo aos mais miseráveis. Muito pelo contrário, observamos, por parte de alguns, o desenvolvimento de mecanismos e investimentos apropriados para catar. Os que possuem mais recursos conseguem estruturar uma rotina de trabalho muito mais planejada e profissional, deixando de ser um trabalho meramente provisório e sazonal. De alguma maneira, buscam aprimorar o desenvolvimento das atividades e circunscrever a honra de quem cata naquilo que adquirem e no que mantêm por intermédio dessa atividade, no sentido de prover a casa com honestidade. A 
ética não está meramente no trabalho, mas naquilo que provém do trabalho, naquilo que é dever, honra e responsabilidade do sujeito que tem a função de prover a família ou no fato de doar-se a ela com os meios que possui.

É importante saber lidar com as urgências da vida cotidiana. Isso nos parece fundamental para quem se encontra numa condição dificil economicamente, desprovido de condições básicas que o coloca naquilo que podemos definir, em certo sentido, como vulnerabilidade social. Porém, estar numa condição de vulnerabilidade social é também condição manifesta de quem é debilitado e vulnerabilizado pela fragilidade de seus vínculos sociais. Essa condição pode ter diversas origens e perpassar inúmeros aspectos, dentre eles a falta de conhecimentos, o adoecimento em suas diferentes formas, a ausência de vínculos afetivos ou profissionais, entre outros. A debilidade econômica é apenas mais um quesito na composição desse rol de aspectos. A vulnerabilidade social, enfim, não é algo padrão e deve ser tratada como processo que se manifesta de diferentes formas nas vidas concretas dos diferentes sujeitos, nos diferentes segmentos e realidades sociais.

Em relação às condições econômicas de quem vive do trabalho, mesmo os trabalhadores que possuem empregos formais, o processo de vulnerabilidade não deve ser descartado, pois os empregos e as rotinas cada vez mais se caracterizam pela insegurança que elas ensejam ao trabalhador. Aspectos relacionados ao risco do desemprego e da concorrência para a manutenção dos postos e das atividades de trabalho são também fenômenos importantes para entender determinados processos de vulnerabilidade social. Ou seja, a insegurança também tem relação com a qualidade dos empregos disponiveis, com a intensa competitividade entre os trabalhadores e com a exploração da mão de obra e sua vulnerabilidade como sujeito e trabalhador. ${ }^{6}$

\footnotetext{
$6 \mathrm{Na}$ atualidade, o padrão de empregos formais possui, cada vez mais, características que o definem por sua fragilidade, ausência de organização coletiva e poder reivindicativo por parte dos trabalhadores, muito em função da grande concorrência pela empregabilidade, dos trabalhos sazonais e da flexibilização das operações, dos baixos salários, ou seja, pela intensiva tecnologização do chão da produção, superexploração da mão de obra e isolamento dos trabalhadores, particularmente em relação aos mais desqualificados profissionalmente, embora se estenda a diferentes níveis de formação e atividades profissionais (ANTUNES, 2010).
} 
Em realidade, a insegurança projeta-se em todos na atualidade que dependem de seu trabalho, principalmente para aqueles que possuem dependência extrema e baixo poder reivindicativo diante das relações de poderes assimétricos. Por isso, ter uma maior diversificação de opções voltadas ao trabalho torna-se uma possibilidade estratégica fundamental aos trabalhadores, principalmente àqueles desprovidos de qualificações específicas e que dependem da oferta de empregos no restrito mercado de trabalho. Isso porque podemos nos encontrar na fronteira social entre a inserção e o abandono funcional, condição amplamente estudada por Castel (1998) como uma aporia de nosso tempo e da sociedade salarial em transição da qual fazemos parte.

Ter um leque de possibilidades de exercício de atividades laborais e não depender exclusivamente de determinados empregadores para o exercício de alguma função econômica é uma "carta na manga" para quem possui esta possibilidade, por mais frágil que seja. Entrar numa atividade, permanecer nela e buscar outras atividades que possa realizar concomitantemente, ou deixar de fazer uma atividade para assumir outra mais vantajosa, podendo voltar à primeira quando lhe convier, torna-se uma condição extremamente satisfatória e demarcadora de certo sentido de poder social para os catadores.

As participações dos trabalhadores, nesse sentido, podem ser também escalonadas e percebidas como possibilidades heterodoxas, na medida em que eles utilizam suas estratégias no campo das atividades e aportes que criam para fugir de uma condição social que poderia torná-los vulneráveis frente a um empregador. Ter mediadores sociais confiáveis que possibilitem a informação e o encaixe a novos empregos e modalidades de trabalho constituise uma situação revitalizadora da condição de não dependência restrita dos trabalhadores frente a poderes e padrões patronais assimétricos. Quebra-se, dessa forma, a radicalidade das condições de dependência e injunções a que estão submetidos determinados trabalhadores no mercado de trabalho. Evidentemente, a independência em relação ao emprego formal e ao trabalho 
autônomo é sempre relativa e circunstancial, dependendo igualmente da confluência das possibilidades e dos encaixes das ofertas e demandas encontradas por parte dos atores. De qualquer forma, em relação aos catadores de materiais recicláveis, alguns efusivamente nos disseram que "chutaram o balde" no trabalho - expressão utilizada para dizer que romperam com a situação em que viviam na relação patrão e empregado - e, dessa forma, assumiram a catação para desenvolver um trabalho com mais liberdade, "sem depender do patrão". Condição essa que nos faz perceber as tensões sociais envolvendo os patrões e trabalhadores e como esses trabalhadores utilizam suas capacidades subjetivas para destoar da órbita do trabalho formal regulado.

Em ambientes de intensas mudanças nas esferas dos trabalhos, seja aqueles que saem do campo para a cidade, da cidade para o campo ou que permanecem em seus locais originários, a condição de estar em ajustamento transforma-se numa forma de conduta permanente. As sociedades mais abertas às mudanças, protagonizadas pela complexidade de relações e fenômenos em seu seio, pelas trocas e dimensões múltiplas que acontecem, possuem atores mais condicionados às transformações e a estabelecer certo comportamento na escala de sua individualização (SENNET, 2014). A individualização, nesse ambiente, não quer dizer necessariamente individualismo e apartamento do sujeito na escala social, como alerta Simmel (1979), mas se trata de um fenômeno alargado pelo maior volume de possibilidades que os sujeitos dispõem para gerenciar os seus relacionamentos e as condições estruturais de vida, mesmo aqueles que, a priori, imaginamos não possuírem aportes vinculantes e condições recursais amplas em suas relações sociais para dar conta das mudanças que os atingem. Diferentemente disso, surpreendemo-nos com as margens de exploração das possibilidades e dos limites que determinados catadores utilizam para incrementar performances e atributos, assim como revigorar práticas e disposições próprias de ser. 
Conformações estratégicas e táticas nas relações com o emprego acontecerão nesse processo que terá a participação ativa do trabalhador da catação. Ter um trabalho e saber aproveitá-lo ao máximo é um estratagema social. Doar-se ao trabalho, saber dividir os contatos e os recursos que ganha, esperar as melhores oportunidades e, até mesmo, saber abandonar e retomar as atividades que executa em momento propício fazem parte de uma condição reflexiva dos sujeitos em seus próprios grupos sociais locais ou nos entrelugares divididos com outros públicos e segmentos sociais, nos lugares de fluxos, locais afeitos pela diversidade dos atores que convergem a eles em momentos determinados e específicos. Em certo sentido, em termos de convivência entre os diferentes, os catadores têm a vantagem de trafegar e perceber realidades diversas que compõem os espaços sociais em que atuam.

Um exemplo disso é o catador Otávio, 42 anos, um dos sujeitos mais dinâmicos que tivemos a oportunidade de conhecer no que se refere às diversas atividades que já executou na vida e que ainda executa em suas andanças pela cidade. Na primeira vez que o avistamos estava na avenida principal da cidade com seu carrinho de reciclagem, com uma máquina de cortar grama e demais instrumentos de ajardinamento (ancinho e pá) dentro dele. Corria muito. Num primeiro momento parecia que estava com pressa, mas nos deu o devido tempo e oportunidade para conhecê-lo e falar um pouco de si, respondendo nossas indagações. Explicou-nos que faz a reciclagem e, paralelamente, faz trabalhos de ajardinamento, que consistem em limpeza de pátios em residências. Explicou que tem a ideia de mais adiante ter o seu próprio galpão, comprar de outros catadores e vender às empresas de reciclagem, não precisando mais sair para catar na rua. Disse que "estragou" a coluna puxando um carrinho pesado. Cata há vinte e dois anos pela cidade. Além disso, Otávio trabalha num projeto da Prefeitura de inserção social pelo trabalho. Nesse projeto geralmente vai para o interior do município para consertar pontes e realizar todo tipo de manutenção em estradas, onde também estabelece contato com moradores locais e recolhe latinhas e pequenos materiais plásticos, que coloca num saco 
para trazer para a cidade. Estabelece, assim, um trabalho duplo, o que lhe dá um rendimento diferenciado. É astuto e prático no que faz e tenta aproveitar diferentes oportunidades para incrementar sua renda pessoal e familiar.

Enfim, hoje sai com seu carrinho para reciclar, cata no trajeto dos trabalhos em que se insere e diz que não se limita à catação: "vou aonde pagam mais, mas não deixo a minha reciclagem". A reciclagem é um suporte permanente que lhe dá segurança. Mais do que isso, permite-lhe transitar e aceitar ou refugar propostas de trabalho. Aceita o que paga mais, mas não se submete a tudo o que lhe pedem, ou seja, de alguma forma estabelece critérios para a sua atuação. Caso não tenha trabalho formal, tem a catação que lhe abre a possibilidade de ganhos certos e imediatos.

Pagava aluguel e morava num lugar que o bueiro entupia, ligava para a Prefeitura e eles não faziam nada. Alagava a rua. Um dia limpei o bueiro e coloquei o material que entupia no meu pátio. Um vizinho viu e me deu uma ideia de trabalhar com esse material. Antes deixava de pagar uma conta, não tinha dinheiro, daí cortavam a água ou a luz. Hoje não deixo de pagar nada, tenho sempre a possibilidade de ter um dinheiro com a reciclagem (Otávio, catador, 42 anos).

Ter pelo menos o mínimo para prover a casa, pagar água e luz para que os outros não vejam vestígios de vulnerabilidade econômica e social por parte do responsável da casa já é algo muito importante e que justifica a proposta de permanecer na reciclagem. Trata-se de um trabalho líquido e certo, de conquista de rendimento financeiro, que dissipa a preocupação em não conseguir cumprir as atribuições do responsável pela família. Não ter água e luz cortada é algo importante, mais que o próprio serviço de abastecimento de energia e água em si, pois repercute no âmago da honra e moral do indivíduo que busca manter a família com dignidade.

No mesmo sentido, Fernando, outro catador que trabalha há muitos anos na catação, embora seu serviço principal seja de gari, nos caminhões do lixo, também é muito eloquente em seu depoimento:

[...] até penso de parar, mas se eu parar, com o salário que eu ganho... até ergo as mãos, dou graças a Deus... mas se eu parar eu me quebro mais. Então eu tenho que continuar, pra mim dar a volta. Mas eu dou graças a Deus que sobrevivi e conheço muita gente que sobrevive disso 
ai. Eu neste sentido, a minha única queixa, é neste sentido. O senhor mesmo é testemunha do que eu tenho aqui. Tudo o que eu tenho é da reciclagem. É através da reciclagem, então eu, graças a Deus, não tenho o que me queixar (Fernando, catador e gari, 51 anos).

Enfim, a certeza que os sujeitos adquirem em saber que conseguirão prover a família com elementos básicos para sua sustentação tem um caráter fundamental. Ou seja, ratifica ao homem a segurança dispositiva que manterá sua honra como responsável do núcleo familiar, evitando os falatórios e julgamentos em sua circunvizinhança. Não se perde, pelo menos, o status de importância e respeito por essa circunstância; caso isso aconteça, o rompimento das relações familiares torna-se possibilidade muito forte de efetivamente acontecer. A reciclagem, com isso, torna-se um trunfo, um aporte de segurança tática, contrariando outras formas de pensar que imaginam o trabalho de catação como uma atividade estritamente desarticulada, degradante, em importância e sustentação moral. A lógica do trabalho na catação é outra e deve ser entendida em seu contexto; dependerá de quem a percebe em sua complexidade e de quem a pratica, principalmente.

Em relação às mulheres, percebemos que a lógica social não se diferencia da dos homens em suas concepções de independência, de prover ou ajudar a família economicamente. O que as diferencia fica condicionado a uma questão de escala de atuação e importância. A mulher que trabalha fora de casa "ajuda" o parceiro a prover a família, embora não se desprenda das responsabilidades de chefe da casa e dos afazeres domésticos. A mulher chefe-de-família, separada ou viúva do marido, ainda sem outro companheiro, por opção ou falta de oportunidade, elabora um senso de responsabilidade e correspondência ao provimento da família, agindo no trabalho da catação de forma mais sistemática, ponderando alguns elementos que revigoram e ressignificam a unidade doméstica e as condições de vida da família. ${ }^{7}$

\footnotetext{
7 Fonseca (2000) realiza uma analisa das dinâmicas de relacionamentos e do poder em vilas populares na cidade de Porto Alegre / RS. Neste trabalho também aprofunda a divisão do trabalho relacionada a gêneros, bem como as formas de expressões e condutas estabelecidas pelos atores no sentido de autopreservações em ambiente de forte ambiguidade, ou seja, de ampla reciprocidade solidária e violenta.
} 


\section{Associação e individualização estratégica}

Um conjunto de aspectos que observamos e que nos intrigou no campo de estudo diz respeito à relação entre origem social, necessidades de ajustes nos relacionamentos e formas de organização para o trabalho. Entre os catadores com quem mantivemos contato, as ocupações profissionais que exercem são, em geral, indicações de outras pessoas ou se viabilizam nas trocas de informações e vantagens adquiridas entre parentes e familiares. Outro aspecto importante é a relativa rotatividade de funções profissionais entre os atores estudados, principalmente aqueles que não possuem uma profissão definida no meio urbano. Como muitos são originários do meio rural ou guardam disposições sociais desse meio por intermédio de seus parentes, inserem-se no mercado de trabalho urbano sem qualificação específica e buscam resguardar-se com o auxílio de seus afins consanguíneos. Isso também vale para os mais jovens, que nasceram propriamente na cidade e que, mesmo assim, possuem muita dificuldade para conseguir e manter o primeiro emprego.

Em relação ao trabalho, alguns aspectos intensificam os ajustamentos dos que lutam para inserir-se e alcançar certo nível de estabilidade na sociedade. Tais aspectos correspondem às práticas e às confabulações associativas existentes voltadas as atividades laborais coletivas. Evidentemente estas experiências de trabalhos coletivos são as mais variadas possiveis e o termo associativismo está distante de ser proferido nas falas dos catadores. Porém, chama-nos atenção o caráter de formalidade e informalidade de alguns empreendimentos e trabalhos coletivos, executados por grupos de pessoas que possuem um lastro de relações familiares e parentais significativo. Isso nos faz pensar no quanto é possível o trabalho dos catadores estar articulado por relações de proximidade predefinidas, a partir de relações parentais, pela divisão do terreno de suas casas, socializando o espaço para moradia e trabalho ou no centro de uma proposta cooperativa, no galpão de reciclagem. Observamos que em todas as cooperativas que conhecemos na cidade existem elos básicos de parentescos, mais de dois grandes grupos de parentes por cooperativas, muitas vezes, o que auxilia, até certo ponto, a conformação de um 
caráter de confiança, de espontaneidade e de acessibilidade a determinados indivíduos para ingressar nos empreendimentos cooperados.

Podemos perceber, porém, que as garantias de ajuda mútua e reciprocidades que os relacionamentos promovem também podem gerar incertezas e colocar à prova os processos de integração dos indivíduos nos grupos de trabalho, a exemplo do que acontece nas próprias comunidades onde vivem tais atores e demais segmentos de camadas populares, locais em que há uma dinâmica conflitiva muito própria dos grupos populares a partir de status e hierarquias particulares e específicas configuradas nas famílias e nas comunidades de uma forma geral.

No seio das relações parentais e em comunidades, onde, em muitos casos, se estabelecem composições de trabalhos coletivos em meio às incertezas do mercado de trabalho formal ou pelas opções espontâneas desenvolvidas pelos sujeitos, hierarquias de poder se manifestam constantemente para traçar o status de importância de cada ator no seio da comunidade. A honra e o prestígio são aportes capitais necessários e permanentemente buscados e/ou conservados pelos sujeitos, dentro de uma noção de "estratégia de sobrevivência" (FONSECA, 2000), pois a demonstração de força e poder podem ser a melhor forma de posicionamento e garantia de não ser molestado em um ambiente de relativa violência e apreensão do risco de vida e exploração.

Num ambiente em que os recursos para o exercício de poder são diversos, embora o poder econômico de um indivíduo pouco se sobressaia em relação aos outros, a condição expressa de poder pode variar na graduação do poder simbólico, seja na demonstração da virilidade do corpo físico e do traquejo do homem ao transitar pelo espaço da rua, seja na maledicência de boatos e enredos de intrigas desenvolvidos pelas mulheres que se correspondem com vizinhos e parentes no ambiente mais restrito da casa.

Em grupos populares de sociedades desiguais, em que a personalidade tem grande relevância e poder de influência, Fonseca destaca as hierarquias de poder que subsidiam as esferas dos relacionamentos, as quais fazem parte de 
um sistema em que a honra dos indivíduos possui um princípio de valor supervalorizado, estabelecendo lastros de conduta e apreensão das importâncias resolutivas do que define o que é determinado sujeito. Os padrões de valor do homem e da mulher estão dispostos na rede de relações estabelecidas, e a honra, nesse sentido, deve ser constituída e mantida pelos atores. Os sujeitos, enfim, têm deveres a cumprir na sociedade e, no jogo das relações e atributos a serem cumpridos, reverberam disputas e luta por reconhecimentos e distinção entre os participantes dos grupos sociais. Ou seja, a força e coragem dos homens e a fofoca das mulheres são balizadores de conduta e parâmetros da escala hierárquica de poder. Há que sempre testar o outro, maximizando poder quando possivel e depauperando a outra parte para conseguir uma posição satisfatória na hierarquia social. Conforme Fonseca (2000, p. 27):

Conseguir rebaixar o status de um faz com que suba o do outro. Se os homens testam-se constantemente uns com os outros por atos de coragem, bravura, etc, as mulheres afrontam-se pela fofoca. Esses casos de agressão mútua são, apesar de sua aparência anárquica, regidos por um código de comportamento, raramente aplicado aos estranhos, que marca os limites do grupo.

São notórias as confabulações hierárquicas nas camadas populares e a luta pelo desenvolvimento das posições nas escalas de relacionamentos, conforme pudemos destacar e concordar com as conclusões de Fonseca. O cuidado para falar do outro, a forma devida de expressar-se e, em alguns momentos, o ataque à moral e ao comportamento alheio é decisiva para o narrador alçar-se a uma posição superior e inferiorizar seu oponente, ou mero vizinho e consanguíneo, o qual estabelece e faz comparações na escala das posições. A ponderação quando se fala da vila e do lugar em que se vive é também pendular, ora se tem a posição de defesa e de negação no sentido de tecer qualquer comentário sobre as relações desenvolvidas na comunidade "não vou na casa de ninguém", "não sei da vida dos outros", "é só trabalho e casa a minha vida", "eu nunca visito os parentes", "boca fechada não entra mosca" -, ora a posição é de ataque e de classificação do outro - "aquele ali é cachaceiro", "aquela ali é fofoqueira", "os caras só fazem bagunça no trabalho", "esse é um 
vizinho clássico, roubou de todo mundo no galpão" - (conforme trechos variados de nossas entrevistas).

Nas relações no ambiente de trabalho associativo formal, nas cooperativas de trabalho na reciclagem, geralmente é reproduzido o fenômeno sistêmico de posições e lutas por aquiescência do status moral, em que a honra se funda nos processos qualificativos dos indivíduos. É visto que em determinados momentos as brigas e intrigas no interior das associações são potencialmente mais fortes e sistemáticas, e a desconfiança pelo uso e a malversação dos recursos financeiros das associações não é o único motivo de discórdia, embora seja sempre um mote para a ampliação de discussões e desentendimentos. Temos que considerar que as redes de intrigas e desconfianças não necessariamente se originam no seio das cooperativas, mas é algo mais amplo e diz respeito até mesmo à relativa intimidade dos grupos e das relações familiares e comunitárias, ou seja, contornar os conflitos associativos de trabalho não é algo que se relacione apenas a um problema de gestão do empreendimento especificamente.

As relações de poderes, nesse sentido, estão na epiderme das relações sociais, o que nos faz descartar certo idealismo ou romantismo ao analisar as relações mais íntimas ou recônditas atribuídas aos estratos populares e, particularmente, aos trabalhadores das cooperativas que se movimentam esgrimindo seus afetos e desafetos no jogo presencial e conflitivo das posições de semelhanças e antagonismos. Assim como qualquer grupo humano, o sistema de crenças, valores, práticas e poderes dinamizam as possibilidades e revigoram os hábitos culturais.

Podemos perceber que esse fenômeno pode ser entendido como um processo de autodeferimento de status em função da diferenciação de um ator em relação a outros, ou de um grupo em relação a outro grupo, ou seja, a partir da perspectiva identitária, condição que destaca apreensões de elementos simbólicos e auto referenciados (SILVA, 2014). Tal processo, no caso em destaque, vai ao encontro de um princípio de participação individual ou grupal 
de sujeitos que transitam e estabelecem relações com os que consideram seus iguais e diferentes, no interior e no exterior dos coletivos urbanos e associativos de trabalho. No transcurso do trabalho, seja na forma cooperativa ou autônoma, percebemos um princípio liberal popular muito arraigado entre os catadores, com amplas interfaces com a noção de moralidade e de honra que compartilham em sociedade. Esse princípio faz alguns até mesmo refutarem, de forma peremptória, qualquer tipo de associação voltada ao trabalho coletivo, "não dá certo trabalhar reunido, dá sempre bagunça", nos diz Fernando, um catador que possui experiência de 22 anos nesse trabalho e que já cruzou com muitas pessoas que executam ou executaram a catação pela cidade ou em organizações associativas.

Assim como percebemos que aqueles catadores com disposições sociais mais próximas do meio rural, sejam eles recém-chegados ou aqueles com idade mais avançada e que passaram suas vidas muito mais próximos do horizonte rural que o da cidade, possuem uma tendência maior em aceitar o trabalho organizado coletivamente. Ou seja, esses são muito mais afeitos ao coletivo e de comparar a sua vida pregressa com os hábitos dos moradores da cidade. Posição talvez mais próxima das características do trabalho coletivo do meio agrícola e rural. Por outro lado, os que possuem características eminentemente urbanas, que nasceram na cidade e possuem práticas mais maleáveis no interior do espaço urbano, com proposições mais individualistas do ponto de vista da execução do trabalho, referendam suas práticas menosprezando a importância do trabalho coletivo, fora da alçada da família e da parentela. A desconfiança aqui é sempre uma prática. Porém, as condições de origem dos trabalhadores não são inteiramente determinantes quanto à organização ou não do trabalho cooperativo, uma vez que outros elementos entram em interseção, principalmente quando relacionados a um associativismo espontâneo criado pelos próprios laços parentais nas comunidades em que vivem.

\section{3. "Vai indo, vai indo" - movimento como recurso constante e totalizante}


A expressão "vai indo, vai indo" ou "fui indo, fui indo" chamou nossa atenção quanto ao número de vezes em que foi enunciada a partir de nossos contatos no campo de pesquisa. Percebemos que o "vai indo" transcende ao significado literal de ir a algum lugar específico, pois exprime, fundamentalmente, a ideia de movimento em termos de uma dimensão ampla e relacionada às capacidades de cada um em transitar e desenvolver sua vida. Ou seja, sugere práticas e contornos que o indivíduo estabelece ao longo de suas trajetórias de vida e trabalho. Tal desenvolvimento de práticas, porém, não é algo linear, mas traz expressa a ideia do enfrentamento, dos percalços da vida e do arrojo para enfrentá-los. O "vai indo" é, de certa forma, o emblema de uma incursão de lutas que os sujeitos travam cotidianamente e os impulsiona para o enfrentamento de situações. Em síntese, é a maturação do contexto do vivido e de enaltecimento de que tudo é transitório na vida, pois a mudança é permanente. Mesmo com dificuldades, se vai longe; as coisas acontecem e não são perenes, o que configura sempre uma relação de ambiguidade entre dificuldades da vida e esperança em resolvê-las, pois o tempo também faz a sua parte, e os ajustamentos acontecem.

A saga de cada um é sempre incompleta; relativamente tem o seu início marcado por momentos e fatos originários configurando trajetórias de vida de quem as narra e constrói a sua devida importância causal para explicar a própria realidade. Os fatos mais corriqueiros nas trajetórias de nossos entrevistados são: evasão do meio rural; pobreza extrema neste ambiente; abandono dos pais; desemprego cíclico e estrutural na cidade; doença e ou morte de algum familiar, abalando e desestruturando em parte a unidade do grupo. A expressão "vai indo" traz também a ideia de conquista, de ir aos poucos reconstruindo a vida na dificuldade e na esperteza, "sabendo levar as coisas, se vai longe", expressam alguns catadores, reforçando suas conquistas e suas forças exemplares.

Tal forma de resumir e colocar-se no mundo, de alguma maneira, desafia os sujeitos e os reforça dentro de uma noção de performance individual na 
condução de ações sociais. De alguma forma, também condiciona uma ideia de esperança e necessidade de prosseguir seu processo de vida e condicionamentos.

Fui indo, fui indo. Batalhando, batalhando. Trabalhando pra lá e pra cá. E dando uns pulo, pra poder viver. Eu não parava, trabalhava pra um e pra outro. Trabalhava por dia, plantava feijão pra um e pra outro. Das 8 ao meio dia, da uma e meia até às 6 da tarde. Era puxado. Trabalhava pros caras que tinha colônia lá, mas era puxado. Meu Deus do Céu... Não adianta. Tem que seguir um caminho ou outro. Não dá para o cara ficar parado, não dá. É como eu lhe falei, vim com 6 mudas de roupa de lá, 24 anos atrás... e fui indo, trabalhando, trabalhando, trabalhando. E hoje... não vai em quatro bolsa o que já tenho. Viu, viu... não vai em quatro bolsa o que já tenho. Já é um comecinho (Vilson, 62 anos, catador da cooperativa Recibela).

Nesse sentido, o "vai indo" também enseja a possibilidade do retorno, passos de ir e vir, no ir longe e poder voltar. Isso porque a expressão tem uma conotação abstrata do desenvolvimento do trajeto, que pode significar também a ideia de retorno como um elemento de ascensão social ou, até mesmo, de retrocesso. Trata-se dos alcances de quem se movimenta, de sua persistência e suas condições de sobrevivência em diferentes espaços em que transita, seja no âmbito das distâncias percorridas, seja na capacidade de desvelamento das histórias de vida que cada um quer transparecer, o que só se revela a partir dos casos concretos e do contexto da fala do entrevistado. Essas movimentações compõem as modulações dos espaços que os sujeitos percorrem simultaneamente, da sua casa - do espaço de seu domínio - até os lugares da rua, dos locais de conquistas permanentes, vãs e transitórias. Trata-se de âmbitos que formam suas narrativas e nos ajudam a perceber o alinhamento de elementos que compõem os modos de vida de cada um. Espaços esses definidos pelo uso da sapiência, agilidade e astúcia, condições fundamentais para quem quer sobreviver e melhor colocar-se, aproveitando as oportunidades e os recursos disponiveis nos campos em que se inserem e atuam.

Dessa forma, a mobilidade é em si mesma um recurso. Faz parte e sedimenta um aporte de relações que não se circunscreve apenas pela dimensão econômica, embora ela seja particularmente importante. Estabelecer contatos e ser móvel é, de certa forma, abrir canais de relacionamentos, de 
informações, de apadrinhamentos, de trabalhos múltiplos, de reconhecimentos, de ganhos de objetos e favores, além de toda uma gama de recursos disponiveis oriundos de políticas e projetos sociais, públicos ou privados.

Mediante restrições de poder econômico, social, político ou simbólico, articular-se com quem os têm em demasia é sempre uma possibilidade de ganho extra e de influências múltiplas. Os contatos que os trabalhadores podem realizar, com a devida persistência que devem possuir, são de fundamental importância. E, dessa forma, são muito salientados pelos catadores. Porém, traçar prioridades, ter fé em Deus e seguir adiante é atributo para os mais fortes - encaram desse modo os entrevistados. Caso isso não seja possivel, de nada adianta a ajuda alheia. Essa ideia estabelece uma noção de responsabilidade que provém dos próprios sujeitos, não sendo meros resignados a um eventual problema ou às dificuldades da vida, mas sim atores que perseguem determinados projetos e valores em suas relações com os outros. Fora isso, é cair no ostracismo, na verdadeira exclusão social, em que nem os seus pares emitem respeito, em que não há mais nada a ser feito. Esse estágio é algo muito extremo, com forte conotação à indigência e à morte social, se é que isso seja possível integralmente de alguma maneira, porém vale como alegoria das relações nas quais o respeito e a moral estão consignados à desenvoltura de práticas e responsabilidades compartilhadas.

O fragmento da fala de Valter, um homem com postura corporal forte, de meia idade, com características de homem do campo, sempre com chapéu e fala pausada, revela: "já tive tudo, ...casa, família e perdi tudo pra cachaça, indo morar na rua". Hoje tenta recompor-se na vida, com uma companheira que conheceu na praça, também moradora de rua, fugida da clínica de dependentes químicos. Valter diz ter a ideia de que tudo depende dele para dar continuidade ao processo de integração social que busca restabelecer.

Foi indo. Nem panela nós não tínhamos. Já fui ajeitando as coisas. Deus disse que ajuda, mas também a pessoa tem que se ajudar. Mas é normal, se o cara não se ajuda, não tem ninguém que possa ajudar ele. Ele tem primeiro que se ajudar, para que o outro poder fazer a outra 
parte, né? É bem assim que funciona. Tamo feliz, tamo com saúde, tamo tranquilo. Porque a vida continua (Valter, catador, 50 anos).

Os passos para retomar uma nova rota, porém, não são simétricos e progressivamente evolutivos no sentido de galgar etapas e ter a certeza da conquista de um determinado parâmetro de inserção social no mundo do trabalho. A catação, nesse sentido, cumpre uma primeira possibilidade de inclusão e é uma possibilidade de renda continua a esses sujeitos e para outros que cruzam seu caminho pela cidade.

Ir longe, nesse sentido, representa demonstrar um leque de movimentações constantes e opções desenvolvidas nas trajetórias e histórias de vida. Movimentações que se fazem por bloqueios, dificuldades, insistências e definições nas decisões dos atores, gerando permanências e recomeços nas formas de ser e estar, nas formas de agir e desenvolver estratégias e táticas de relacionamentos, sem deixar de exercer características próprias na forma de expressão corporal, linguística, representacional e identitária. Para isso, a atuação no trabalho é sempre maleável e exige dos atores o discernimento e a possibilidade de se fazer escolhas que os levem a considerar não apenas o trabalho em si, mas tudo o que envolve a dinâmica da vida e o senso prático das trocas, dos reconhecimentos e ganhos imediatos e não imediatos. O depoimento de Sandro também é bastante elucidativo nesse sentido, em relação ao processo de constituição do trabalho e da montagem de seu patrimônio pessoal.

Homem do céu, era sofrido. Paguemo aluguel um ano. Mas desde sempre, desde piá, eu tive cavalo, né. Sempre briquiei cavalo, gostava de carreira. Gostava de carreira, de carreira e coisa. Daí comecei a briquear uns carros velho. Uns carros velho prá lá, uns carro velho pra cá. Daí foi indo, foi indo, foi indo. Daí que eu tinha dois, um Escort e um Corcel, né. Dai arrumei lá um terreno pra briquear com o Escort. "Bah", eu disse, "briquiei o Escort com o terreno". Daí comecei a limpar, morava ali em cima, comecei a limpar todo o terreno. Daí apareceu as madeira pra briquear no corcel. Daí peguei o corcel e briquei. Daí, graças a Deus, saímos do aluguel.

Sandro é um homem de origem rural, nasceu em uma família de agricultores que faziam diversos serviços nas propriedades em que trabalhavam. Pela sua pouca idade quando veio morar em Passo Fundo e pela 
disposição aprendida de seu pai, um homem "meio andarilho", segundo Sandro, condicionou suas práticas em um teor de flexibilidade permanente, porém com forte conotação e hábitos rurais. Circunscreve hoje sua prática principal de trabalho na reciclagem, tem uma empresa de reciclagem própria, mas também lida com animais para o uso doméstico. Nunca deixou de ter o seu cavalo. Até pouco tempo vendia leite para a vizinhança, mas revelou que "perdeu os amigos pela falta de pagamento do leite" que fornecia aos vizinhos, ou seja, as pessoas compravam para pagar em momento posterior e nunca saldavam a dívida com Sandro. Mora num bairro periférico da cidade, divisa entre os espaços urbano e rural. Afirma ainda que não consegue deixar os animais, gosta de tirar leite das vacas e vagar com o cavalo sem destino nos finais de semana.

De personalidade forte, Sandro nunca se sentiu satisfeito em ser empregado dos outros. Fez vários "acordos" de trabalho, buscando sempre certa liberdade para transitar entre diferentes espaços, seja rural, para onde retornou diversas vezes para cuidar de animais em granjas da região ("eu sou meio veterinário, sabe!"), seja no espaço urbano, basicamente junto a um empregador com quem trabalhou por 14 anos de forma intermitente, pois saiu formalmente de seu emprego algumas vezes. Uma dessas ocasiões foi para receber o Seguro Desemprego, com o propósito de incrementar a sua renda e fazer a carteira de motorista para poder transportar material reciclável para si e para o próprio empregador do qual tinha se desvinculado formalmente, mas de quem, na prática, ainda era funcionário.

O Seguro Desemprego, nesse sentido, é um aporte utilizado por alguns trabalhadores na medida em que ele permite uma renda extra, ou seja, incrementar a renda familiar em determinados momentos de dificuldades ou de um projeto de consumo ou trabalho, à medida que o trabalhador se disponha a sair do emprego formalmente, às vezes não de fato, tendo a possibilidade de acionar o seguro e receber uma importância financeira paralela à remuneração por serviços que continua a executar de forma "fria", ou seja, sem registro na carteira profissional. Caso não fosse assim, seria difícil comprar ou investir em 
algo, pois não teria condições de pagar algum investimento apenas com o salário mensal ordinário. Sair e voltar para o emprego ou migrar para outra atividade de trabalho de forma não registrada em carteira de trabalho, enfim, são possibilidades sempre refletidas e conjugadas às necessidades permanentes e imediatas dos trabalhadores.

Possibilidades que são compostas de profunda racionalidade focada a determinados fins: otimizar recursos disponiveis que embasem certa ascensão nas condições de vida dos trabalhadores; desfrutar, em certos casos, de algum recurso financeiro sem precisar trabalhar, mostrando para todos a esperteza e a astúcia necessária para manipular e enfrentar todas as dificuldades do dia a dia - condição que mostra a força do indivíduo e sua sapiência na comparação com seus pares, elevando seu status moral perante o grupo com o qual se identifica. Ser propositivo em práticas que possam consubstanciar um leque de outras possibilidades e resistir a determinadas formas de mando e exploração no trabalho são condições sempre acessadas por esses trabalhadores, embora nenhum processo dessa natureza seja líquido e certo. Mas é igualmente composto por tensões e retrocessos quanto à condição do sujeito frente a seu grupo e a seus empregadores.

Da mesma forma, outra estratégia recorrente para buscar vantagens alocadas e previstas pelos catadores se dá pela composição e articulação de ganhos e nas trocas que realizam entre conhecidos. Conforme tivemos oportunidade de constatar, inclusive o entrevistado anterior é uma referência nesse sentido, as trocas entre integrantes das camadas populares se dão muito por intermédio dos bens que cada um adquire e disponibiliza para um eventual negócio. O bem que tem maior liquidez nas trocas é o automóvel e as motocicletas, chegando a ser interpretados como uma poupança por parte de quem os possui, em comparação a investimentos financeiros de outras classes sociais. Ou seja, investe-se no automóvel para, em um momento mais propício, transacioná-lo. Nesse sentido, o automóvel não é apenas um bem considerado de uso propriamente dito, mas um objeto de troca. Geralmente investe-se em algo palpável, caso contrário, pode-se "gastar o dinheiro com outras coisas" sem 
constituir um valor econômico que se possa vender em um momento determinado. Outros utensílios também são muito valorizados como bens de troca, como televisão, materiais de construção e cavalos (esse mais restritos ao público que lida com esse tipo de animal). Observa-se, dessa forma, uma economia popular, em que os itens econômicos são, em certa perspectiva, muito voláteis, e as mudanças em torno da casa, do trabalho, da disponibilidade de trocas e ajustes de bens são constantes.

As urgências que determinados sujeitos buscam superar, a exemplo dos problemas de doenças na familia que os fazem deslocar-se à cidade ou, simplesmente, para investir na melhoria ou na compra da casa própria, geralmente desprendem os sujeitos de relações longas de trabalhos, principalmente as mais precarizadas e que não lhes dão certeza de permanência e remuneração satisfatória. Em função da baixa remuneração, da superexploração do trabalho, até mesmo pela forma irregular do pagamento de salários e da alta taxa de esforço físico exigida, os trabalhadores geralmente relativizam a própria importância do trabalho formal e dos vínculos que possam estabelecer na atividade a que estão submetidos. Esta relativização, no entanto, traz implícita certa ambiguidade na tomada de decisão. Por um lado, ser autônomo e trabalhar com materiais recicláveis dá certa liberdade de horário e na forma de executar a atividade; por outro lado, o montante regular de dinheiro no final do mês, bem como os direitos trabalhistas - férias, décimo terceiro salário, etc. - e outras garantias sociais também podem ser levadas em consideração por alguns trabalhadores. Exemplificamos este ponto com o depoimento da catadora Soraia, que agora trabalha numa empresa de limpeza pública terceirizada: "eu juntando papel, eu me sentia... eu me sentia, Eu. Com carteira assinada o dinheiro tá ali. Tem segurança, mas... [não tem liberdade, está presa a um sistema de trabalho controlado por uma hierarquia funcional]".

Em certo sentido, isso aflora tensões, desejos e percepções do mundo e das possibilidades que cada um pode ir buscar ao viver em um contexto de trabalho e dos aportes que possui ou pensa possuir. Ter maior liberdade para 
trabalhar e transitar por diferentes espaços, de qualquer forma, torna-se uma possibilidade de amealhar diferentes "recursos" (oportunidades) pelos lugares em que se passa e pelos contatos e vínculos sociais que se pode estabelecer, condição de suma importância e contrária a trabalhos repetitivos e fechados em ambientes fabris. ${ }^{8}$ Por essa fórmula, a catação também nutre o desejo da autonomia, de liberdade, de comunicação, "de se fazer o próprio dinheiro", sem estar circunscrito ao mando gerencial e a trabalhos extremamente penosos e mal remunerados, independente de ser a própria catação de rua um trabalho bastante dificil, "sacrificado", como alguns se referem, "pegando sol e chuva na rua". Além, é claro, de que o preço pago pelo material é aviltante e desproporcional a tudo aquilo que faz e produz o catador.

Longe de querermos idealizar as condições atuais do trabalho da catação, mas, de alguma forma, necessitamos ter um olhar mais refinado quanto às questões que envolvem processos concretos. Nesse contexto, mais uma vez, alguns catadores nos indicam como ideal a conjunção de atividades e trabalhos diferentes, como é o caso também de Fernando, que diz ter pelo menos três atividades laborais em seu escopo de atividades. Executa trabalho como gari em uma empresa pública de limpeza urbana, concursado e com registro na carteira profissional, além de ser catador de materiais recicláveis e pedreiro nas horas vagas, realizando construções para si e para terceiros.

Porque a reciclagem é assim, a reciclagem hoje dá bem, tem dias que dá e tem dias que não dá. Eu digo pro senhor, se neste mês eu ganhar dois mil, se eu não tiver outro emprego, eu tenho que pensar no dia de amanhã. Principalmente no inverno, no inverno ele descai. No inverno ele descai, é chuvarada. Daí o senhor só tem aquela renda. Só tem aquela renda. Se ganhar os dois mil e gastar os dois mil e não pensar no dia de amanhã, o cara vai se quebrar. É bom manter outros lados pra tu manter o que tu tá fazendo. Entende? Porque se tu depender só disso aí... os lixo bom de Passo Fundo é segunda, sexta e sábado. Os dias bom. O resto da semana, se tu sair... no meu causo, se tu sair, é pra gastar. Só gasto em combustivel. Então tem três dias bom em Passo

\footnotetext{
8 Um exemplo contundente de emprego com trabalho precário, repetitivo e mal remunerado na região de Passo Fundo fica a cargo dos grandes matadouros e frigoríficos de carnes que empregam em sua maioria mulheres. Muitas catadoras afirmaram já ter trabalhado nos frigoríficos da região, mas não aguentaram o ritmo de trabalho e priorizaram o trabalho da catação e do cuidado da casa. Com muitas delas tivemos contatos. Outro exemplo de trabalho precário é a construção civil, essa mais relacionada ao trabalho masculino, empregando um grande contingente de pessoas na cidade.
} 
Fundo. É segunda, sexta e sábado. O resto da semana se quebra (Fernando, catador e gari na empresa de limpeza pública, 51 anos).

Ao falar de seus gastos, da incerteza da reciclagem e de sua disposição para a vida e para o trabalho, Fernando completa:

Do meu lado eu já levo controlado. O que eu ganho, o que eu devo e o que eu tenho que pagar. Eu já levo tudo controlado. Claro, que se eu não tivesse este emprego, que eu tenho hoje, graças a Deus, eu sobreviveria bem. Além da reciclagem, eu tenho mais uma profissão, mas eu ia me judiar bastante. Ia me judiar, pela idade que eu tenho já. Meio castigado, castigado pelo tempo ai. O cara daí se judia mais. Então é isso meu amigo, sou bem sincero em dizer pro senhor, enquanto Deus me der força nos braços e força nas pernas pra correr e caminhar, eu não largo da reciclagem. O meu sonho, e eu entrego nas mãos Dele, é construir muita coisa ainda. Embora eu tenha que ter começado lá atrás, mas eu tô em tempo de conseguir. Porque um terço do que eu tenho é das obras e mais de um terço do que eu tenho aqui é da reciclagem. Então eu não tenho que me queixar da reciclagem. Tem que fazer, tem que fazer (Fernando, catador e gari na empresa de limpeza pública, 51 anos).

A pluralidade de fenômenos no feixe de direções e possibilidades é algo já apontado neste texto. Nem todos os elementos e atores estarão postos de forma homogênea e retratarão suas trajetórias indistintamente. O que nos cabe considerar, contudo, são determinadas características de disposições que se assemelham no contínuo das relações, em função da origem social de quem transita pelo espaço e vai moldando suas integrações, táticas, estratégias e subjetividades. Por este ponto de vista, as relações e características dos sujeitos não são estanques, mas móveis e adaptativas ao longo de suas próprias trajetórias, embora possam carregar determinadas tendências que também irão se modificando ao longo do percurso da vida. Lembrando que nenhuma trajetória é igual à outra, mas particular, recebendo a influência de diferentes fatores, sejam aqueles que se circunscrevem a questões estruturais econômicas, sociais, políticas - e que alcança a todos, sejam aquelas de fórum mais íntimo, familiar, local, eventual, específica, mediante formas de socializações particulares, formação escolar, gênero, gerações etárias diferenciadas, etc., aspectos esses que só mediante uma leitura articulada e pormenorizada poderão ser melhor compreendidos. 


\section{Considerações finais}

Este trabalho buscou discorrer sobre lógicas de ações sociais e práticas desenvolvidas por trabalhadores que, de uma forma ou outra, possuem relação com o trabalho de catação de materiais recicláveis. Compreendemos a partir disso que os catadores são atores sociais dinâmicos na sociedade, pois, de forma até mesmo inconsciente e reativa, produzem possibilidades afirmativas de trabalho como recursos sociais ao trafegar em espaços diferentes em uma determinada cidade ou região, articulados em diferentes escalas sociais, seja com a família, com a comunidade e com a sociedade de uma forma geral. E, assim, perfazem percursos complexos, pendulares e heterogêneos na medida do alcance de suas possibilidades, mudanças e fixações.

Por isso, a impossibilidade de querer enquadrar o trabalhador que exerce a atividade de catação como um simples catador de materiais recicláveis, o qual, inadvertidamente, poderiamos supor que leva uma vida miserável, exercendo apenas a mesma atividade durante longas jornadas de trabalho, torna-se imprópria e inadequada a uma proposta epistemológica que queira ser crítica e abarcar a complexidade dos "mundos vividos". E, na mesma medida, torna-se inapropriado enquadrar o catador como receptáculo reificado que possa sofrer a intervenção das instituições públicas de forma irrestrita para que sejam adequados às "condutas aceitáveis" definidas e normatizadas pelo Estado, sem a sua participação nas definições das ações e políticas sociais.

O catador é mais que um catador. Devemos entendê-lo como um trabalhador multifacetado, que atende a suas demandas extra e intratrabalho desenvolvido. Ele é catador ao estar catando, mas isso não quer dizer que se resuma a essa atividade. Nesse sentido, alertam-nos sobre suas dinâmicas concretas, suas inserções nesta atividade, suas condições de permanência e de manifestações ao enfrentar obstáculos e possibilidades no trabalho e na vida cotidiana. O ir e vir permanente, a astúcia ordinária utilizada no dia a dia e os padrões que estabelecem para catar e exercer outras atividades podem 
demonstrar isso, fazendo-nos compreender melhor a complexidade das vidas e circunstâncias que perfazem em suas trajetórias na forma arruada do dia a dia.

Alguns caminhos nos sinalizam que a rotatividade de empregos também é um recurso utilizado pelos catadores e que pode ser compreendida também por uma equação complexa oriunda das relações desenvolvidas pelos atores, como buscamos abordar anteriormente. Tais lógicas são circunscritas no movimento pela busca da não dependência dos trabalhadores aos empregos precários que acessam circunstancialmente em momentos de suas trajetórias laborais pela cidade. Para isso, estar articulado em várias frentes de possibilidades de trabalho e ajuda de parentes, nos percursos entre os diversos lugares que transitam, pode ser algo interessante, uma vez que o nível de dependência do indivíduo a um trabalho específico ou a uma pessoa que os emprega torna-se amenizada ou quase nula. O movimento continuo, nessa circunstância, pode ser considerado um handicap positivo, por vincular o indivíduo numa rede de relações mais ampla, em detrimento de uma reduzida rede de relações e constante obrigação profissional a um único empregador.

Nessa condição, podemos encontrar trabalhadores urbanos com baixa qualificação profissional, a exemplo dos catadores de materiais recicláveis, que transitam literalmente pelas cidades, pois firmam múltiplos pactos, alguns esporádicos, outros mais duradouros, com vistas a se articularem e multiplicarem vantagens, como o aprendizado de diversificadas tarefas, obtenção de ganhos materiais, como roupas, calçados, comidas, materiais de construção, para o uso pessoal e das suas famílias.

Nesse sentido, demais membros da família e afins servem como mediadores entre o mundo mais próximo da casa e das relações propriamente ditas do trabalho e do mundo externo a esse ambiente. Enfim, nem tudo é tão simples e esquemático como se possa imaginar e depende realmente das disposições construídas e das mesclas de experiências de cada sujeito e de seu grupo social. No movimento embalado pelos polos da individualização e da 
coletivização das atividades laborais e comunitárias existem diferentes possibilidades que se mesclam e tornam os movimentos complexos.

A única certeza é a necessidade de enaltecer a ideia de que os catadores não são meros desassistidos e excluídos socialmente, pois são sujeitos avivados de sua condição e transitam pela cidade racionalizando suas práticas e esboçando uma margem de suas disposições sociais. A vulnerabilidade social de alguns é evidente, pois vivem no rigor de dificuldades econômicas severas, assim como em condições precárias de moradias, embora não seja a maioria que possa ser caracterizada dessa forma, muito pelo contrário, pois são fundamentalmente heterogêneos em suas formas de atuação e nos níveis de importância que atribuem a este e a outros trabalhos que executam pela cidade. Alguns, dessa forma, veem a catação como mero, mas importante complemento da renda ou uma "carta na manga" (atividade reserva) que possa ser acionada a qualquer momento; outros a percebem como fonte principal para a sua manutenção a medida em que investem nessa atividade e estabelecem critérios permanentes para o seu exercício.

As questões salientadas por esta pesquisa estiveram em consonância em compreender a dinâmica dos catadores e suas relações avivadas no campo de suas condutas. O que cabe esclarecer, porém, que mesmo compreendendo os catadores como sujeitos dinâmicos e atuantes na sociedade, diante de lógicas que os integram a um circulo social, onde suas práticas são operadas por táticas, estratégias e subjetivações salientadas por suas dinâmicas culturais, esses indivíduos podem ser enaltecidos pelas políticas públicas no sentido de serem valorizados em suas ações, pois elas estão permeadas por valores, formas de expressão e conhecimentos apreendidos ao longo de suas experiências de vida e trabalho.

\section{Referências}

ANTUNES, Ricardo. Adeus ao trabalho? Ensaio sobre as metamorfoses e a centralidade no mundo do trabalho. São Paulo: Cortez, 2010. 
CASTEL, Robert. As metamorfoses da questão social: uma crônica do salário. Petrópolis: Vozes, 1998.

CASTELLS, Manuel. A sociedade em rede. (A era da informação: economia, sociedade e cultura; v.1) São Paulo: Paz e Terra, 1999.

CERTEAU, Michel de. A invenção do cotidiano: a arte de fazer. Petrópolis: Vozes, 1998.

DUBET, François. Sociologia da experiência. Lisboa: Instituto Piaget, 1994.

FONSECA, Cláudia. Familia, fofoca e honra. Porto Alegre: UFRGS, 2000.

MAGNI, Cláudia T. Nomadismo Urbano: uma etnografia sobre moradores de rua em Porto Alegre. (Série Conhecimentos 35) Santa Cruz do Sul: Edunisc, 2006.

RÜCKERT, Aldomar. A trajetória da terra: ocupação e colonização do centronorte do Rio Grande do Sul - 1827 - 1931. Passo Fundo: Ediupf, 1997.

SENNETT, Richard. O declinio do homem público: as tiranias da intimidade. Rio de Janeiro: Record, 2014.

SILVA, Tomaz T. (Org.) Identidade e diferença: a perspectiva dos estudos culturais. Petrópolis: Vozes, 2014.

SIMMEL, Georg. A metrópole e a vida mental. In: VELHO, Otávio. O fenômeno urbano. Rio de Janeiro: Zahar, 1979. p.11-25.

TEDESCO, João C.; CARINI, Joel J. (Orgs.) Conflitos agrários no norte gaúcho. Passo Fundo: IMED, 2010. 